\title{
The Two Cultures Debate Turns Sixty
}

\author{
DANYL McLAUCHLAN
}

One refreshing way to frame partisan intellectual debates is to think about status. If we strip away all the rhetoric and attempts to occupy the moral high ground what we're often left with is the claim that some person or discipline should be raised or lowered in status, usually relative to some rival group. This is not a bad way to think about C. P. Snow's famous "Two Cultures" lecture and the debate it sparked. "Scientists should be higher in status," is the essence of Snow's argument. The literary critic F. R. Leavis-who emerged as Snow's most ferocious opponent-was far less generous towards his own tribe: both literary and scientific intellectuals other than himself should be much, much lower in status, Leavis seemed to feel, especially Snow who should have no status at all.

Of course they said more than this. C. P. Snow-Sir Charles, by 1959, the year of his Two Cultures lecture; later Baron Snow - trained as a physicist. He studied under Rutherford at the Cavendish, gained a $\mathrm{PhD}$ from Cambridge, became a scientific bureaucrat rather than a researcher and rose to great heights in the civil service. But his main claim to fame was as a novelist: he published a series of books called Strangers and Brothers. They were well-received at the time, mostly forgotten now. I found a copy of his most celebrated work The Masters in the stacks of my university library and found it unreadable, but his contemporaries liked it. He was compared to Proust; even whispered about as a possible candidate for the Nobel Prize, although mostly by himself.

In May of 1959 Snow delivered the prestigious Cambridge Rede Lecture. The Two Cultures and the Scientific Revolution suggested that over the last thirty years British intellectual life had divided into separate streams: a scientific one and a literary one, now existing in camps of mutually uncomprehending hostility. As a novelist with scientific training Snow could claim to represent both sides, but his sympathies were overwhelmingly with the scientists. To him they were the heroes of modernity: they "had the future in their bones," while literary intellectuals and other humanities types were "natural luddites," proudly ignorant of even the most elementary scientific principles. This mattered, Snow claimed, because the problems of the world, especially the third world, could only be solved by science and the prosperity it created. Because of this, Snow charged, the literary elites who comprised the UK's dominant intellectual class, and who scorned science, posed an existential civilisational threat.

There was a huge public response to Snow's lecture, which was quickly hurried out in book form. It went viral before the phrase existed, and intellectuals in both the UK and US rushed in to defend or attack the thesis. But Snow's greatest enemy, F. R. Leavis, director of English studies at Downing College, Cambridge, took two years to respond, also in a lecture, also at Cambridge. Leavis was not as publicly celebrated as Snow-no one was ever going to nominate him for a Barony - but he was, in the long run, more influential. Leavis, more than any other person, developed the idea of English and English Literature as an elite academic university subject. "He did for literature what Russell and Wittgenstein did for philosophy," one of his biographers notes: he normalised the idea of a high caste of literary experts pronouncing on a body of complex theory in a formal, technical jargon inaccessible to the public. (Almost, you might say, like scientists.) 
His lecture is harder to summarise than Snow's. He dismissed the two cultures thesis in a cursory way, declaring there were not two cultures and that literary intellectuals did not need to know the slightest thing about science. Then he questioned Snow's assumptions about economic growth as a panacea to the problems of the world. Maybe, he suggested, science and modernity were creating more problems than they solved? Maybe all this growth, he wondered, is coming at some terrible cost to our society? And he interrogated the idea of a public intellectual. Why did the media and the public listen to C. P. Snow? Why were his ideas respected? Leavis answered his own question: society listened to Snow because he repeated its unquestioned assumptions back at itself. Surely the true critic, the true thinker-and here we imagine Leavis gently resting his hand on his own chest - questions the self-evident values and assumptions of a society. He challenges the clichés and asks the deeper questions.

There were two ideas here - the critique of economic prosperity and the media's role in manufacturing ideology - that would later become canonical concepts in left-wing intellectual thought. (It is tempting to see this debate as that of Sir Charles, a right-wing aristocrat championing science, with the working-class Leavis speaking truth to his power, but Snow was a lifelong socialist while Leavis was famously sceptical of Marxism.) Leavis failed to distinguish himself as a prophet, however, because he was - ironically - rather a poor writer. It simply didn't occur to him that the media and the public paid more attention to Snow because Snow was a far more effective communicator, with his repertoire of novelist's tricks and talent for catchphrases. He did not help himself by beginning his lecture with a series of hyperbolic insults: Snow was not a novelist at all, Leavis announced, nor did he know anything about science, and these were such absurd claims to make about a widely respected novelist with a doctorate in physics that even his fellow critics lined up to condemn Leavis who, many commentators felt, had largely proved Snow's thesis about the ignorance and arrogance of modern literary intellectuals.

\section{Silent Spring}

By 1963 the dust had mostly settled on the two cultures debate, and Snow tentatively suggested that what we actually needed was some kind of "third culture" combining the insights of the arts and sciences. Around the same time, the publication of Rachel Carson's book Silent Spring caused an uproar in the US that made the Snow-Leavis spat look civil by comparison. Carson's book was about the widespread environmental destruction caused by the indiscriminate use of pesticides, but it was written as a work of literature: what we'd now call "science communications." It provoked a furious response from the chemical industry and its political allies (the fact that Carson was attractive but unmarried was a probable sign she was a communist, President Eisenhower told his aides), but the findings of the book were verified by government reports and it is now credited as the foundational text of modern environmentalism.

Scientists - as Snow conceived of them-were men, and they were men of a future in which technology was an uncomplicated good. Carson was, bafflingly, not only a woman and a scientist - her training was in marine biology_-but a critic of technological modernity. Some forms of progress, she argued, were having a devastating effect on the natural world, and even threatening human health. But she wasn't a critic as Leavis conceived of the word: she made a scientific argument, not a cultural one, and this was what made it so powerful. Poets and other representatives of the cultural sphere had been complaining about modernity since at least the eighteenth century - think of Goldsmith's deserted village, Blake's dark satanic mills - but poets always said such things. Carson was something new: a critic of modernity speaking the language of modernity; the language of science. 
If you go into any campus bookstore today you find shelves of books in Carson's tradition: mostly written by physical and social scientists or journalists trained in those disciplines. Occasionally they reach the status of global phenomena: Piketty's Capital in the Twenty First Century was the latest work to reach Carson-like levels of influence, and it is rich in literary references: for Piketty, Jane Austen and Balzac dramatise the inequality of the nineteenthcentury economic model. The humanities are well represented on the opposite side of the store: novels, poetry, essays; but the elite form of academic cultural criticism Leavis championed has largely vanished from the public conversation.

\section{"From the Margins of an Almost Invisible Literature ... ."}

Here is an often-quoted excerpt from Snow's speech:

A good many times I have been present at gatherings of people who, by the standards of the traditional culture, are thought highly educated and who have with considerable gusto been expressing their incredulity at the illiteracy of scientists. Once or twice I have been provoked and have asked the company how many of them could describe the Second Law of Thermodynamics. The response was cold: it was also negative. Yet I was asking something which is the scientific equivalent of: Have you read a work of Shakespeare's?

I asked a group of Biology $\mathrm{PhD}$ students if they could describe the second law of thermodynamics. "Something to do with heat?" they guessed. They'd learned thermodynamics as undergraduates but no longer knew the laws by heart because the knowledge just wasn't very useful to their research.

The second law is easily stated: the total entropy of a closed system always increases over time. But what is entropy? It is: "the level of disorder within a system." It's a notoriously slippery concept: John von Neumann reportedly advised young scientists to use the word entropy liberally when applying for grants, because no one quite knew what it meant. It is linked to another mysterious phenomena: time. Entropy gives time its directionality; its arrow. "You cannot stir things apart," as a character in a Stoppard play puts it. This gives thermodynamics deep philosophical implications: the (still unproved) long term fate of the universe is possibly that of "thermodynamic heat death," and this is a consequence of the second law.

In his 1968 novel Do Androids Dream of Electric Sheep the science fiction author Philip K. Dick introduces the concept of "kipple":

Kipple is useless objects, like junk mail or match folders after you use the last match or gum wrappers or yesterday's newspaper. When nobody's around, kipple reproduces itself. For instance, if you to go bed leaving any kipple around your apartment, when you wake up there is twice as much of it. It always gets more and more. There's the First Law of Kipple, "Kipple drives out nonkipple." We can roll the kipple-factor back; But we can’t win.

Kipple is consumer capitalism's manifestation of entropy. Dick's novel, along with much of the "new wave" of science fiction published in the 1960s and 70s, was obsessed with entropy and the second law, decay, social and environmental collapse. Prior to the new wave the genre was widely regarded as fun but juvenile: fantasies about heroes in rocket ships battling aliens ("Talking squids in outer space," as Margaret Atwood put it.) But in the 60s science fiction became political and social and philosophical. It was critical of modernity and progress. "A 
good science fiction story should be able to predict not the automobile but the traffic jam," announced Frederik Pohl. Science fiction became literature in other words, although, fifty years later, many novelists in Snow's tradition and critics in Leavis's have yet to figure this out.

The new wave enjoys a bleak recognition today as critics acknowledge the prescience of the work, pointing to Phil Dick's warnings about the implications of artificial intelligence; J. G. Ballard's prophecies of global warming, environmental catastrophe, information societies, endof-history dystopia. "Everything is becoming science fiction," Ballard announced in 1971. "From the margins of an almost invisible literature sprang the intact reality of the 20th century."

In Snow's day there was no intellectual alternative to the high culture championed by Leavis, but now, if members of Snow's scientific culture are reading fiction it is often science fiction; and if any novel inspired them to become scientists it's often a work in this genre (this is also true of the social sciences: Isaac Asimov's Foundation trilogy seems to be especially popular among economists). The global superstar of early twenty-first century sci-fi is the Chinese writer Liu Cixin, a former computer scientist: the plot of his most famous novel is driven by unsolved problems in physics, cosmology and game theory, and deals-eventually-with entropy and the heat death of the universe. But it begins during China's Cultural Revolution with a political dissident reading Silent Spring.

\section{Paradigms Lost}

The nadir between the two cultures came during the 1990s with the "science wars," a protracted conflict between scientific realists and postmodern cultural critics. It played out mostly in the United States and France, along roughly the same lines as the Snow-Leavis debate: scientists felt disrespected; cultural critics felt that the unquestioned assumptions of scientists were hubristic and dangerous.

The most proximate intellectual cause was The Structure of Scientific Revolutions, a book published in 1962 by the philosopher Thomas Kuhn. Kuhn rejected the model of "normal science" prevalent among scientists at the time, which he described as a naive belief in the progressive accumulation of true facts and falsifiable theories about the world. Actual science is cultural and episodic, he argued, and to describe how this works he introduced a word now ubiquitous in corporate jargon: "paradigms." A paradigm is a scientific model. It explains most known facts, e.g., the atomic theory explains most known facts in chemistry, the structure and behaviour of fluids and gases and solids. But there are "anomalies" that cannot be explained by the existing paradigm. (Continuing the example, electron configurations in transition metals are sometimes - controversially — cited as an anomaly in physical chemistry.)

The way Kuhn claims science really works is that some scientists investigate anomalies but most just ignore them and go about doing research that confirms the truth of the current paradigm. Then there's some technological or conceptual breakthrough: a "paradigm shift," like the Copernican overthrow of Ptolemaic cosmology or the development of special relativity, and this explains the anomalies by replacing the current model. But these paradigm shifts are often political and social as much as scientific; French scientists question a paradigm because it came from Germany; older scientists fight against new paradigms rather than accept the evidence; younger scientists ignore grave flaws in new theories that are well explained in the old. 
Kuhn's book was very controversial: it attacked the assumptions embedded in Snow's speech, assumptions that were universal in the scientific community at the time (still not unknown today): that science is the rational and objective accumulation of universal truths. Decades later there's an acknowledgement that Kuhn was onto something; that although objectivity is the ideal, science is a human endeavour, biased and flawed, and the world is complex and often counterintuitive. Reality needs to be understood through models, and different models show us different things. Undergraduate students are often warned that some of what they're taught will be proved wrong; rendered obsolete; that there are unsolved problems in their fields - the incompatibility between classical and quantum physics is the most glaring - that may require a paradigm shift to solve. That what is true today might not be true in the future.

But there's a second way to interpret Kuhn's ideas. What if there is no truth? Maybe there is no objective world? Maybe there is only oppression and language and power, and language has no inherent meaning while power is invisible and ubiquitous? This is the world of philosophical postmodernism, a syncretism of ideas about linguistics, literary theory, philosophy, politics and social change that became enormously influential in humanities departments, especially in France and the United States, during the 1980s and 90s.

It's fashionable to make fun of the postmoderns, especially their addiction to neologising, often incomprehensible jargon, but a lot of their key ideas are now conventional wisdom: in the drinking water. It was the postmoderns who drew attention to speeches like Snow's and the assumptions embedded in them. When Snow casually talks about scientists as men, or regards the people of "the third world" as problems to be solved by the scientists of the first, he's not just making an argument, a postmodern theorist would say: he's manufacturing ideologies that privilege men above women and white colonial powers over those of the global south, and then concealing that ideology by presenting himself as a rational, impartial scientist. And all of these assumptions were so widespread in his society, Snow probably didn't even realise he was doing so. The more dominant the discourse, the postmodernists argued, the more natural it seems and the more radical it sounds when anyone questions it.

This is what Leavis was gesturing at when he suggested that Snow failed as a public intellectual because he repeated society's comfortable, unquestioned assumptions back at itself, but he lacked the theoretical infrastructure to develop his argument. The postmoderns had many, many theories (although they weren't theories as scientists would know them, testable empirical statements about the world. The very idea of empiricism is laughable in the postmodern context).

One of the most celebrated theorists was the philosopher and literary critic Michel Foucault. Foucault claimed that science was innately political and oppressive. "Reason" was really just a system of control that allowed scientists and their political masters to claim they were never wrong. Anyone marginalised by a "rational society"-women, artists, gay people, ethnic minorities - or who spoke up against it could be dismissed as "nonrational," or even institutionalised. Rationalism, Foucault claimed, was totalitarian.

Foucault's theory of knowledge/power wedded to Kuhn's theory of paradigms and paradigm shifts became tools for the postmodern critique of science (a critique that Kuhn himself seems to have strongly disagreed with). Scientists weren't saying anything true about the world, the postmodern argument went, they were just making up elaborate stories-referred to as narratives, or discourses - to justify oppressive economic and social and political systems, 
while presenting those systems as "natural" and "rational." And there was some truth to what the postmodernists said, as we shall see (although they also said truth didn't exist). But the way they said it was catastrophically bad.

When postmodern theorists discussed literature or history or politics they-usuallyapproached their subjects with a deep and sophisticated understanding of the discipline. But none of the very famous, very celebrated postmodern theorists who attacked science in the 1980s and early 90s knew anything about it, and this led to a torrent of hilariously uninformed, now legendary postmodernist claims: Luce Irigaray arguing that $\mathrm{E}=\mathrm{mc}^{2}$ is a sexist equation, Jacques Lacan insisting that $\sqrt{-1}$ is "equivalent to the erectile organ." They were documented by the French physicists Alan Sokal and Jean Bricmont in their book Fashionable Nonsense, published in the UK as Intellectual Impostures. Sokal and Bricmont demonstrated-very convincingly - that the luminaries of postmodern theory repeatedly used scientific terms in ways that made no sense. The postmoderns weren't talking about science in any meaningful way, Sokal and Bricmont showed, while also implying that they weren't talking about anything in a meaningful way. When, say, the sociologist Jean Baudrillard discussed "variable refraction hyperspace" or "indefinite fractal scissiparity" it wasn't science, or a criticism of science, it was just gibberish masquerading as profundity. Fashionable Nonsense was lavishly covered in the science press; reviewed glowingly by the biologist Richard Dawkins and the philosopher Thomas Nagel, among others, and it is still remembered decades later as a decisive "emperor's new clothes" moment when scientists proved that their critics in the humanities were frauds.

\section{Postmodernism turns out to be "true"}

But the decades since the 90s have seen scandals across the sciences that point to the very problems the postmodernists tried-and completely failed - to communicate. After the 2008 global financial crisis, economics became (and in many eyes, still is) a poster child for political ideology masquerading as science. Economic models of human rationality or the efficacy of markets appear to have little correspondence with the behaviour of actual humans or actual markets.

Another example: polls and surveys around the world identify sexism, harassment and ethnic discrimination as endemic problems in the STEM fields (STEM is a fusion of the hard and applied sciences: Science, Technology, Engineering and Medicine). A number of bias studies show that papers are less likely to be published if they're submitted by a lead author with a female name. Countless drug studies only conducted clinical trials on white people, or men, or both, and later determined that the medications were ineffective or had side effects when prescribed to women, or people of colour (the asthma medication ventolin and the anticoagulant warfarin are the most famous examples). Facial recognition algorithms routinely generate false positives when identifying women or minorities. Other forms of weak AI often make discriminatory judgements because the databases the machine learning algorithms are trained on are human generated: they have the bias and discrimination of human society embedded in them.

And since the 2010s the social and life sciences have been confronted by "the replication crisis": a methodological failure rather than a social one. Many scientific findings, including some of the most significant in psychology and biology, have proved to be difficult or impossible to reproduce, calling entire lines of research into question. In May of 2019 a major study into a number of candidate genes for depression found no evidence whatsoever for the many findings that had linked a handful of genes to the mood disorder. "How on Earth could 
we have spent 20 years and hundreds of millions of dollars studying pure noise?" the head author wondered.

Most of the answers to that question point to the academic publication process and how closely wedded it is to winning grants and career promotion. If two research teams study the same phenomena - psychological priming, say, or an interesting candidate gene - and one of them uses meticulous methodology and finds nothing interesting while the second team reruns their experiment until they get statistically significant results, or retrofits their questions to match the results they obtained, then uses these dubious findings to write a really exciting, surprising, counterintuitive paper, this is far more likely to be published in a top journal than a null result, or a finding that confirms an already known result, even though it is much less likely to be true.

There's still debate over the precise scale of the reproducibility problem, and what the solutions might look like. And there's vehement denial there's any controversy at all, mostly coming from the scientists whose work is most compromised - the Princeton psychologist Susan Fiske refers to researchers pointing attention to reproducibility failures as "methodological terrorists." (Just as Kuhn's social model of science predicts: science is heavily impacted by social phenomenon like status and politics.)

The wider relevance of all this to the "two cultures" debate is that the postmodern critique of science, hopelessly executed as it was, turned out to be very prescient. Scientists were fabricating stories and presenting them as objective truth, often without realising it, and many of this was done in the interests of personal or economic or political power. The postmodernists could have served their self-appointed roles as the ruthless critics of modernity very well: if they'd learned anything about the institutions they were critiquing, or managed to explain their ideas to anyone other than themselves.

\section{Sixty Years On}

Snow's two cultures theory is a model, a paradigm, and today if we look at intellectual life through his framework we can see the still-separate cultures, along with anomalies like science fiction writers and environmental activists. We can also see Snow and his enemy, F. R. Leavis, as problematic representatives of their respective tribes: Snow representing the scientists who deludes themselves that their vocation grants them an objective, unbiased view of the world; Leavis representing the cultural and literary intellectuals who want to critique science without learning anything about it, then struggle to communicate with anyone who doesn't already agree with them; both of them overly concerned with status, rather than truth.

Six decades after the controversy, Snow's culture appears triumphant. STEM enrolments are surging. Their departments occupy new buildings bulging with expensive instruments, while the humanities are being "downsized" and merged as student numbers decline. The US statistics indicate a significant gender factor: STEM disciplines are no longer seen as restrictive to women, who now outnumber men at most tertiary institutions, and who now make up the majority of students in some STEM fields, notably psychology (engineering and computer science are still overwhelmingly male).

But the two cultures model always concealed as much as it revealed. It was never clear where the social sciences fitted in, even though economists - then and now-have more power over the direction of society than either scientists or cultural critics. Are lawyers an intellectual culture? They play a more prominent role in public debates around issues such as freedom of 
speech and constitutional law than either of Snow's tribes. Do journalists and other media figures present a distinct intellectual culture, the purpose of which is, perhaps, to tell us how the world really is instead of how politicians, lawyers and other intellectuals present it? Or are they a subset of the arts? Many contemporary novelists see themselves fulfilling a similar function. In the mid-1970s Ballard wrote:

We live in a world ruled by fictions of every kind - mass merchandising, advertising, politics conducted as a branch of advertising, the instant translation of science and technology into popular imagery, the increasing blurring and intermingling of identities within the realm of consumer goods.... For the writer in particular it is less and less necessary for him to invent the fictional content of his novel. The fiction is already there. The writer's task is to invent the reality.

If we look at contemporary intellectual life from outside the two cultures perspective we see a much more diverse intellectual landscape. Cross-disciplinary studies and centres are flourishing. Writers like Carson and the new wave who were once anomalies are now norms. Popular science books are bestsellers. Even the hard sciences have literary stars, like the recently deceased physicist Stephen Hawking (although there is some uncertainty in the publishing industry over how many readers actually finish such works). We are living through an unprecedented golden age of nonfiction, especially scientific nonfiction in which writers like Elizabeth Kolbert and Siddhartha Mukherjee routinely win Pulitzer prizes. Criticisms of modernity are routinely made on scientific grounds: the global movement to prevent catastrophic climate change is a scientific project. And science itself is slightly more selfcritical and self-conscious than it was in Snow's day, although the replication crisis suggests it still has work to do: that the problems of "truth" and "the real," which have troubled academics since Plato founded the academy, have not quite been solved.

The future of the cultural and literary humanities is less obvious. The new caste of literary academic elites that Leavis did so much to create appears to be dying, or at least declining in status. During the nineteenth century both classics and theology dominated intellectual culture in the West, only to dwindle in the twentieth. Both still exist academically, albeit in a state of near irrelevancy. Perhaps this is the bleak fate of Leavis's literary high culture? Or perhaps it will reinvent itself. There is more writing today than ever before; more culture; more cultural and political and social and scientific and economic problems; more of everything for a critical culture to speak of, if it can learn to speak of it to an audience other than itself. 